\title{
Use of seaweed-based biostimulant (Ascophyllum nodosum) on ornamental sunflower seed germination and seedling growth
}

\author{
Patrick Luan Ferreira dos Santos ${ }^{1 *}$, Alessandro Reinaldo Zabotto ${ }^{2}$, Half Weinberg Corrêa Jordão ${ }^{2}$, \\ Roberto Lyra Villas Boas ${ }^{1}$, Fernando Broetto ${ }^{3}$, Armando Reis Tavares ${ }^{4}$
}

\begin{abstract}
Seaweed extracts are employed as biostimulants due to their beneficial effects on crop growth and yield. Ascophyllum nodosum seaweed extract aid to improve seedling growth and development, and decrease seedlings production costs; however, the correct concentration must be used in order to maximize the biostimulant effects. Consequently, this study aimed to analyze the effects of different concentrations of a seaweed-based (Ascophyllum nodosum) biostimulant on ornamental sunflower seed germination and seedling growth. Seeds of ornamental sunflower cv. "Sol Pleno" were sown in polyethylene trays containing commercial substrate. The treatments consisted of dairy spraying $60 \mathrm{~mL}$ of the solutions 0 (control), 5,10 or $15 \mathrm{~mL} \mathrm{~L}^{-1}$ biostimulant on substrate. The experimental design was completely randomized with 4 treatments (concentrations of biostimulant) and 4 replicates $\left(10\right.$ seeds replicate $\left.{ }^{-1}\right)$. The evaluated variables were percentage, index and time averages of germination, seedling height, fresh and dry mass of shoot and roots, and root system morphology (WinRhizo). The increase of the biostimulant concentration enhances seed germination and seedlings development. The concentration $15 \mathrm{~mL} \mathrm{~L}^{-1}$ biostimulant showed the best results for percentage and index of germination and the lowest mean germination time and increase plant height and fresh and dry mass of shoots in relation to the control treatment. Accordingly, $15 \mathrm{~mL} \mathrm{~L}^{-1}$ biostimulant (Ascophyllum nodosum) is recommended for ornamental sunflower "Sol Pleno" seed germination and seedlings growth.
\end{abstract}

Keywords: Helianthus annuus, seedling production, seaweed extract, seed germination.

\section{Resumo}

Uso de bioestimulante a base de alga (Ascophyllum nodosum) na germinação e crescimento de plântulas de girassol ornamental

Extratos de algas marinhas são empregados como bioestimulantes devido aos seus efeitos positivos durante o crescimento e rendimento da cultura. O extrato de algas marinhas de Ascophyllum nodosum podem melhorar o crescimento e desenvolvimento de plântulas e diminuir os custos de produção; entretanto, a concentração correta deve ser usada para maximizar os efeitos bioestimulantes. Nesse sentido, o objetivo deste estudo foi analisar os efeitos de diferentes concentrações de um bioestimulante à base de algas marinhas (Ascophyllum nodosum) na germinação e crescimento inicial de plântulas de girassol ornamental. Sementes de girassol ornamental cv. "Sol Pleno" foram semeadas em bandejas de polietileno contendo substrato comercial. Os tratamentos aplicados consistiram em 60 $\mathrm{mL}$ com 0 (controle), 5,10 ou $15 \mathrm{~mL} \mathrm{~L}^{-1}$ de bioestimulante, pulverizados diariamente. O delineamento experimental foi inteiramente casualizado com 4 tratamentos (concentrações de extrato de alga marinha) e 4 repetições (10 sementes replicadas-1). As variáveis avaliadas foram porcentagem, índice e tempo médio de germinação, altura de plântulas, massa fresca e seca de parte aérea e raízes e morfologia do sistema radicular (WinRhizo). O aumento da concentração de bioestimulante aumentou a germinação das sementes e o desenvolvimento das plântulas, e $15 \mathrm{~mL}$ $\mathrm{L}^{-1}$ de bioestimulante promoveram os melhores resultados para porcentagem e índice de germinação e menor índice de tempo de germinação, além de aumentar a altura das plantas e a massa fresca e seca da parte aérea em relação ao tratamento controle. Assim, a concentração de $15 \mathrm{~mL} \mathrm{~L}^{-1}$ de biosimulante (Ascophyllum nodosum) é recomendada para a germinação de sementes de girassol ornamental "Sol Pleno" e crescimento de plântulas.

Palavras-chave: Helianthus annuus, produção de mudas, extrato de alga, germinação de sementes.

${ }^{1}$ Universidade Estadual Paulista, Faculdade de Ciências Agronômicas, Departamento de Solos e Recursos Ambientais. Botucatu-SP, Brazil.

*Corresponding Author: patricklfsantos@gmail.com

${ }^{2}$ Universidade Estadual Paulista, Faculdade de Ciências Agronômicas, Departamento de Engenharia Rural. Botucatu-SP, Brazil.

${ }^{3}$ Universidade Estadual Paulista, Instituto de Biociências, Departamento de Química e Bioquímica, Botucatu-SP, Brazil.

${ }^{4}$ Instituto de Botânica, Núcleo de Pesquisa em Plantas Ornamentais, São Paulo-SP, Brazil. 


\section{Introduction}

Brazil is among the 15 principal producers of ornamental plants in the world with more than 8 thousand producers cultivating around 350 species and 3 thousand varieties (Schoenmaker, 2019). Floriculture industry is particularly concentrated in the Southeast region, with $45 \%$ of the production, $28 \%$ of the producers and $21 \%$ of the cultivated area in São Paulo State (SEBRAE, 2015; Neves and Pinto, 2015). The ornamental plants production has a high cost-effectiveness if compared to other horticultural crops (Gomes, 2006).

Sunflower is an important industrial crop for oil production, although in recent years it is seeing an increase in its use as a cut flower and dwarf cultivars as pot plant (Cormenzana, 2001). Commercial cut flower sunflowers occupy 400 ha in the UK, with a farmgate value estimate over $£ 7$ millions in 2016 (Hanks, 2017). Currently, the average cost of a standard sunflower in EUA is US\$7.50 for five stems wholesale (U.S. Department of Agriculture, 2017). In Brazil, sunflower and other so-called field flowers that resemble the sunflower are most widely purchased for Easter, being the symbol flower of this date (Junqueira and Peetz, 2017).

The production of seedlings of ornamental plants directly impacts crop growth and yield (Reis et al., 2016). Seed propagation used in the commercial production of ornamental plants guarantees genetic diversity, low cost and easy transport (Grolli, 2008). One of the challenges of the floricultural market is to increase crop productivity by reducing costs without compromising product quality. New approaches have been proposed to stimulate the sustainability of agricultural products and improve the quality of crops and crop-derived products (Ertani et al., 2018). In this sense, alternatives are required in order to increase plant production through new technologies, such as the use of seaweed-based biostimulants.

The use of biostimulants may enhance crop production by increasing the germination rate and the physiological quality and uniformity of plants. Biostimulants also plays an important role in the early stages of plant development, increasing root growth and plant resistance to environmental stresses (Lana et al., 2009). Biostimulant substances from microorganisms are available in the market, and biostimulant efficiency depends of the target species, concentration applied and formulation of the product used (Du Jardin, 2015).

Seaweed has been used as fertilizers or biostimulants in several crops (Sangha et al., 2014). They are composed of macro and microelements, phytohormones such as auxins, cytokines or gibberellins, which can stimulate plant growth efficiently (Górka, 2018). Ascophyllum nodosum is a brown algae collected from the east to the south coast of Canada in an area of approximately 4,000 km (Ugarte et al., 2010) and its extracts produce an array of positive responses in plant physiological processes, such as improving nutrient uptake, root development and photosynthetic activity, as well as producing bioactive molecules acting to prevent plant diseases (Talamini and Stadnik, 2004). Thus, this study aimed to analyze the effects of different concentrations of seaweed-based (Ascophyllum nodosum) biostimulant on the seed germination and seedling growth of ornamental sunflower cv. "Pleno Sol".

\section{Material and Methods}

The seeds of ornamental sunflower "Pleno Sol" were purchased from a commercial producer and sown in polyethylene plastic trays ( 128 cells) filled with commercial substrate (Table 1).

Table 1. Characterization of the substrate used in the experiment.

\begin{tabular}{|c|c|c|c|c|c|c|c|c|c|c|c|c|c|c|c|}
\hline $\mathbf{N}$ & $\mathbf{P}_{2} \mathbf{O}_{5}$ & $\mathrm{~K}_{2} \mathrm{O}$ & $\mathrm{Ca}$ & Mg & $\mathbf{S}$ & Moisture & O.M. & O.C. & $\mathrm{Na}$ & $\mathrm{Cu}$ & $\mathrm{Fe}$ & Mn & Zn & $\mathrm{C} / \mathrm{N}$ & pH \\
\hline \multicolumn{8}{|c|}{----------------- \% (natural ) ---------------- } & dry & \multicolumn{5}{|c|}{----mg/kg (natural) --- } & ------- & natural \\
\hline 0.79 & 0.4 & 0.15 & 1.14 & 2.55 & 0.15 & 8 & 59 & 36 & 1369 & 24 & 9133 & 138 & 44 & $42 / 1$ & 5.8 \\
\hline
\end{tabular}

Substrate composed of: Sphagnum peat, expanded vermiculite, roasted rice husk and macro and micronutrients. O.M.: Organic Matter, O.C.: Organic Carbon.

The seaweed-based (Ascophyllum nodosum) biostimulant was used for experimentation on concentrations of $0,5,10$ or $15 \mathrm{~mL} \mathrm{~L}^{-1}$ biostimulant diluted on tap water (Carvalho et al., 2018). The experiment was daily sprayed with $60 \mathrm{~mL}$ of the experimental solutions. This practice was carried out during 23 days, after which the evaluations of seed germination and seedling growth were carried out:

- Percentage of germination (\%) - calculated by the formula $G=(N / 40) \times 100$, where: $N=$ number of seeds germinated at the end of evaluation (germinated seedlings with height at least $2 \mathrm{~mm}$ );

- Germination speed index (GSI) - calculated by formula GSI $=\Sigma($ ni/ti), where: $n i=$ number of seeds germinating at date ' $\mathrm{i}$ '; ti = date after test installation (Maguirre, 1962);

- Mean germination time (TMG, days) - calculated by the formula $\mathrm{TMG}=(\Sigma$ ni.ti $) /(\Sigma \mathrm{n})$, where: ni $=$ number of seeds germinated per day; $\mathrm{ti}=$ time after test installation; $\mathrm{n}$ $=$ total number of germinated seeds (Labouriau, 1983).

The analyzed variables were seedling height, fresh and dry (forced-air oven dryer at $65{ }^{\circ} \mathrm{C}$ until constant weight) mass of shoots and roots. The analysis of root system morphology was determined by length and the diameter of the root with an optical scanner reader (WinRhizo image analysis system).

The treatments were a completely randomized design with 4 treatments (seaweed-based stimulant) and 4 replicates $\left(10\right.$ seeds replicate $\left.^{-1}\right)$. Data were subjected to 
analysis of variance (ANOVA) and means compared by Tukey test $(p \leq 0.5)$, using "Statistix 10" statistical software.

\section{Results and Discussion}

The best results for all seed germination variables (Table 2) were obtained by the highest biostimulant concentration $\left(15 \mathrm{~mL} \mathrm{~L}^{-1}\right)$, with $300 \%$ higher percentage of germination, $500 \%$ higher germination speed index (GSI), and shortened the mean time of germination (MTG) by half in relation to the control treatment. However, all results were below the ornamental sunflower germination data observed by Santos and Castilho (2018) from 92.18\% to $96.87 \%$, and Silva et al. (2017) from $75 \%$ to $91 \%$. The concentration $15 \mathrm{~mL} \mathrm{~L}^{-1}$ biostimulant was the only treatment that resulted in more than $50 \%$ of germinated seeds; thus, increasing seedling production. Similar effects to the present study were observed in other crops by Gehling et al. (2017) in soybean (Glycine max) and Gehling et al. (2014) in wheat (Triticum aestivum), as the authors verified that higher concentrations of $A$. nodosum seaweed extract improved seed germination.

Table 2. Percentage of germination (PG), germination speed index (GSI), mean time of germination (MTG) of ornamental sunflower seeds in relation to biostimulants doses.

\begin{tabular}{|c|c|c|c|c|c|c|}
\hline \multirow{3}{*}{$\begin{array}{c}\text { Treatment } \\
\text { (ml } \mathbf{L}^{-1} \text { biostimulant) } \\
0\end{array}$} & \multicolumn{2}{|c|}{ PG } & \multicolumn{2}{|c|}{ IVG } & \multicolumn{2}{|c|}{ MTG } \\
\hline & \multicolumn{2}{|c|}{$\%$} & \multicolumn{2}{|c|}{---------------- } & \multicolumn{2}{|c|}{ days } \\
\hline & 20.00 & b & 0.21 & b & 10.0 & $\mathrm{a}$ \\
\hline 5 & 22.50 & $\mathrm{~b}$ & 0.22 & $\mathrm{~b}$ & 10.4 & $\mathrm{a}$ \\
\hline 10 & 25.00 & b & 0.31 & b & 8.3 & $\mathrm{a}$ \\
\hline 15 & 60.00 & $\mathrm{a}$ & 1.13 & $\mathrm{a}$ & 5.6 & $\mathrm{~b}$ \\
\hline DMS & 18.93 & & 0.39 & & 2.2 & \\
\hline CV (\%) & 28.28 & & 39.78 & & 12.1 & \\
\hline $\mathrm{F}$ & $17.51 * *$ & & $22.57 * *$ & & $17.39 * *$ & \\
\hline
\end{tabular}

Means followed by the same do not differ among themselves at the $5 \%$ level of significance by the Tukey test. ** - significant at $1 \%$.

The germination rate and mean germination time are inversely proportional; thus, higher the GSI means lower TMG (Santos et al., 2019); accordantly, seeds treated with $15 \mathrm{~mL} \mathrm{~L}^{-1}$ biostimulant germinated earlier (5.6 days) and higher speed (1.13). Seeds with high GSI and low TMG values are more resistant to the adverse germination conditions, as they germinate faster and the initial stage of development of seedling production is decreased (Oliveira et al., 2009). The GSI and TMG germination data for $15 \mathrm{~mL} \mathrm{~L}^{-1}$ bioestimulant are very similar to the best results observed by Cabral and Castilho (2016) on ornamental sunflower germination (1.10 of GSI and $89 \%$ of germination). Seaweed extracts have the beneficial effect to improve seed germination and seedling establishment making plant propagation more efficient (Sharma et al., 2014). A seedling production program requires a high germination rate in a shorter time (Paim et al., 2016), and the extract compounds increase respiratory rate in seeds, and consequently, the velocity of seedling emergence (Rayorath et al., 2008a). The concentration 15 $\mathrm{mL} \mathrm{L}^{-1}$ biostimulant was the first treatment to germinate, initiating seed emergency 4 days after sown. Positions 1 and 2 had the lowest results with seed germination at $12^{\text {th }}$ days (Figure 1). 


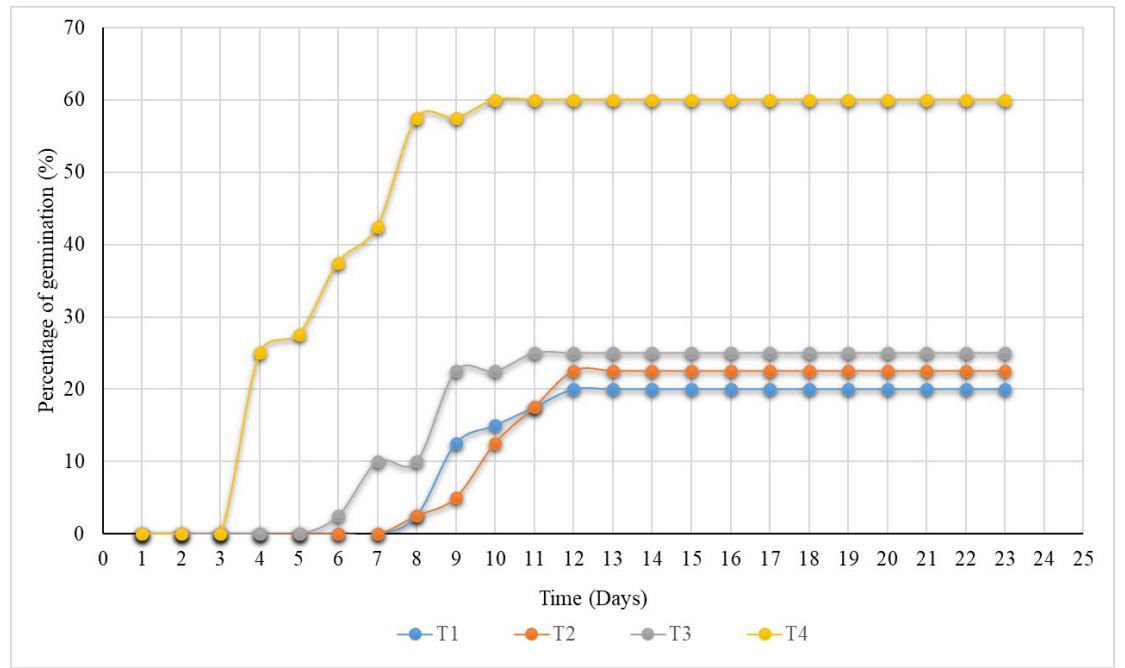

Figure 1. Percentage of germination as a function of the time (days) of ornamental sunflower in relation to biostimulants doses.

The biometrics data of ornamental sunflower seedlings (Table 3) showed that height augmented as the concentration of biostimulant increased, and the best results were reached by $15(6.9 \mathrm{~cm})$ and $10 \mathrm{ml}$ $\mathrm{L}^{-1}$ biostimulant $(5.85 \mathrm{~cm})$ treatments. Plants treated with $15 \mathrm{~mL} \mathrm{~L}^{-1}$ biostimulant were $54.35 \%$ higher than plants of control treatments; this result is an extremely expressive value for a program of ornamental seedlings production. Additionally, data obtained in the present study are higher than those observed by Yari et al. (2015) with 4.68 to $4.86 \mathrm{~cm}$ in different sunflower cultivars. Wheat seeds also had an increase of $6.7 \%$ in height when treated with seaweed extract (Kumar and Sahoo, 2011).

Table 3. Height, fresh and dry mass of shoot and root of ornamental sunflower in relation to biostimulants doses.

\begin{tabular}{|c|c|c|c|c|c|c|c|}
\hline \multirow{3}{*}{$\begin{array}{c}\text { Treatment } \\
\text { (ml } \mathrm{L}^{-1} \text { biostimulant) }\end{array}$} & \multirow{2}{*}{ height } & \multicolumn{2}{|c|}{ Shoot } & \multicolumn{2}{|c|}{ Root } & \multicolumn{2}{|c|}{ WinRhizo } \\
\hline & & Fresh mass & Dry mass & Fresh mass & Dry mass & \multirow{2}{*}{$\begin{array}{c}\text { Length } \\
\mathrm{cm}\end{array}$} & \multirow{2}{*}{$\begin{array}{c}\text { Diameter } \\
\mathrm{mm}\end{array}$} \\
\hline & $\mathrm{cm}$ & \multicolumn{4}{|c|}{ 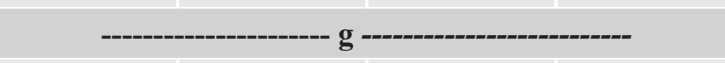 } & & \\
\hline 0 & $3.75 \mathrm{c}$ & $0.3112 \mathrm{~b}$ & $0.0150 \mathrm{c}$ & $0.085 \mathrm{a}$ & $0.0150 \mathrm{a}$ & $50.07 \mathrm{a}$ & $0.33 \mathrm{a}$ \\
\hline 5 & $5.06 \mathrm{bc}$ & $0.3533 \mathrm{~b}$ & $0.0233 b c$ & $0.110 \mathrm{a}$ & $0.0144 \mathrm{a}$ & $59.56 \mathrm{a}$ & $0.34 \mathrm{a}$ \\
\hline 10 & $5.85 \mathrm{ab}$ & $0.4480 \mathrm{ab}$ & $0.0560 \mathrm{~b}$ & $0.115 \mathrm{a}$ & $0.0180 \mathrm{a}$ & 85.08 a & $0.35 \mathrm{a}$ \\
\hline 15 & $6.90 \mathrm{a}$ & $0.5635 \mathrm{a}$ & $0.1025 \mathrm{a}$ & $0.116 \mathrm{a}$ & $0.0195 \mathrm{a}$ & $83.65 \mathrm{a}$ & $0.34 \mathrm{a}$ \\
\hline DMS & 1.65 & 0.15 & 0.04 & 0.005 & 0.009 & 54.00 & 0.11 \\
\hline $\mathrm{CV}(\%)$ & 21.98 & 25.67 & 48.77 & 36.11 & 53.00 & 29.69 & 11.96 \\
\hline F & $12.95 *$ & $12.04 *$ & $23.02 * *$ & $1.45^{\mathrm{ns}}$ & $0.84^{\text {ns }}$ & $2.15^{\mathrm{ns}}$ & $10.15^{\text {ns }}$ \\
\hline
\end{tabular}

Means followed by the same do not differ among themselves at the 5\% level of significance by the Tukey test. ns - not significant; * - significant at 5\%; ** - significant at $1 \%$.

The fresh and dry mass of shoots also augmented as the concentration of the extract increased. The concentrations 10 and $15 \mathrm{~mL} \mathrm{~L}^{-1}$ biostimulant had the best results for fresh mass $(p \leq 0.5)$; while for dry mass the treatment $15 \mathrm{ml} \mathrm{L}^{-1}$ biostimulant were higher $(p \leq 0.5)$ than other treatments (Table 3). Data related to ornamental sunflower fresh and dry mass showed higher mass (1.54-1.85 g and 1.13-1.34 g in Cabral and Castilho, 2016; 1.37$2.14 \mathrm{~g}$ and 0.10-0.23 g in Santos and Castilho, 2018). However, Brito et al. (2014), evaluating the fresh and dry root mass of ornamental sunflower seedlings after 15 days of germination, observed 0.2-0.7 $\mathrm{g}$ and 0.01-0.06 $\mathrm{g}$ respectively, values that are similar to those on the present study. Arabidopsis thaliana (L.) treated with A. nodosum extract increased seedling fresh mass (Rayorath et al., 2008a), probably due that seaweed extract is competent to increase genes expression responsible for endogenous auxin and cytokinin production, hormones in control of plant development (Rayorath et al., 2008b). The precise mechanism by which seaweed extracts act on plant growth and vigor has not yet been fully elucidated, but many of the effects demonstrated by the use of extracts are attributed to a variety of seaweed constituents (Wally et al., 2013), as macro and micronutrients, plant hormones analogs, 
betaines and phenolic compounds (Khan et al., 2009). The application of seaweed Ascophyllum nodosum extract on seeds emphasizes its physiological performance and increase seedling development (Gehling et al., 2014). Fresh and dry mass of root system and WinRhizo data had no significant statistical difference (Table 3). The root length of soybean seedlings was not affected by seaweed extract, which is probably due to the volume of tray limiting root system growth and development (Gehling et al., 2017). The size and volume of the cells in germination tray directly affects root architecture, due to restricted area that limits root growth, which may compromise shoot growth and development (Santos et al., 2019).

\section{Conclusions}

Ascophyllum nodosum seaweed extract had a direct effect on seed germination and seedling growth variables of ornamental sunflower. Its effects were observed on the increase of seed germination variables, reduction of germination mean time and improve seedlings biomass. The concentration $15 \mathrm{ml} \mathrm{L}^{-1}$ biosimulant (Ascophyllum nodosum extract) is recommended to enhance ornamental sunflower "Sol Pleno" seed germination and seedling growth. Additionally, this complex alga compound is natural and had no harmful effect on sunflower seeds.

\section{Author Contribution}

P.L.F.S. ${ }^{0000-0002-1956-1030}$ : Idea of the experiment, field analysis, data collection and analysis, interpretation, preparation and

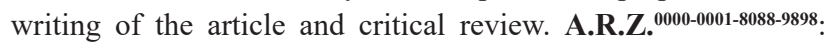
Idea of the experiment, field analysis, data collection and analysis, interpretation, preparation and writing of the article and critical review. H.W.C.J.0000-0002-4871-1085: Data analysis and interpretation. R.L.V.B. ${ }^{0000-0001-7516-4147}$ : Critical review of the article, approval

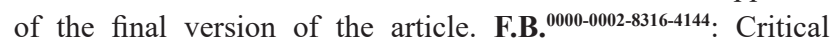
review of the article, approval of the final version of the article. A.R.T.000-0001-6006-4741: Critical review, translation and approval of the final version of the article.

\section{References}

BRITO, K.S.A.; SILVA, V.F.; NASCIMENTO, E.C.S.; FERREIRA, A.C.; OLIVEIRA, L.A. Combinações de substratos agrícolas para o cultivo de plântulas de girassol irrigadas com água residuária. Agropecuária Científica no Semiárido, v.10, n.2, p.125-134, 2014.

CABRAL, E.M.S.; CASTILHO, R.M.M. Germinação e crescimento de girassol ornamental em diferentes substratos. Tecnologia \& Ciência Agropecuária, v.10, n.1, p.29-32, 2016.

CARVALHO, M.E.A.; DE CAMARGO, P.R.; GAZIOLA, S.A.; AZEVEDO, R.A. Is seaweed extract an elicitor compound? Changing proline content in drought-stressed bean plants. Comunicata Scientiae, v.9, n.2, p.292-297, 2018. DOI: https://doi.org/10.14295/cs.v9i2.2134
CORMENZANA, J.M.A. El cultivo de girasol (Helianthus annuus) para flor cortada. Flormarket, n.2, p.55-61, 2001.

DU JARDIN, P. Bioestimulantes vegetais: definição, conceito, principais categorias e regulação. Scientia Horticulturae, v.196, p.3-14, 2015. DOI: http://dx.doi. org/10.1016/j.scienta.2015.09.021

ERTANI, A.; FRANCIOSO, O.; TINTI, A.; SCHIAVON, M.; PIZZEGHELLO, D.; NARDI, S. Evaluation of seaweed extracts from Laminaria and Ascophyllum nodosum spp. as biostimulants in Zea mays L. using a combination of chemical, biochemical and morphological approaches. Frontiers in Plant Science, v.9, p.428, 2018. DOI: http:// dx.doi.org/10.3389/fpls.2018.00428

GEHLING, V.M.; BRUNES, A.P.; DIAS, L.W.; AISENBERG, G.R.; AUMONDE, T.Z. Desempenho fisiológico de sementes de trigo tratadas com extrato de alga Ascophyllum nodosum (L.). Enciclopédia Biosfera, v.10, n.19; p.743-750, 2014.

GEHLING, V.M.; MAZON, A.S.; CAVALCANTE, J.A.; CORRÊA, C.D.; MENDONÇA, A.O.; AUMONDE, T.Z.; VILLELA, F.A. Desempenho fisiológico de sementes de soja tratadas com extrato de alga Ascophyllum nodosum (L.). Revista da Jornada de Pós-Graduação e PesquisaCongrega Urcamp, p.1200-1215, 2017.

GOMES, A.R.M.; D’ÁVILA, J.H.T.; GONDIM, R.S.; BEZERRA, F.C.; BEZERRA, F.M.L. Estimativa da evapotranspiração e coeficiente de cultivo da Heliconia psittacorum L. x H. spathocircinada (Arist) cultivada em ambiente protegido. Revista Ciência Agronômica, v.37, n.1, p.13-18, 2006.

GÓRKA， B.; KORZENIOWSKA， K.; LIPOK, J.; WIECZOREK, P.P. The Biomass of algae and algal extracts in agricultural production. In: Algae Biomass: Characteristics and Applications. Springer: Cham, 2018. p.103-114.

GROLLI, P.R. Propagação de plantas ornamentais. Plantas ornamentais-aspectos para a produção. 2ed. Passo Fundo: Universidade de Passo Fundo, 2008. 201p.

HANKS, G. Sunflowers (Helianthus annuus cultivars) as a field- and tunnel-grown cut flower crop. Stoneleigh: AHDB, 2017. 11p.

JUNQUEIRA, A.H.; PEETZ, M. Brazilian consumption of flowers and ornamental plants: habits, practices and trends. Ornamental Horticulture, v.23, n.2, p.178-184, 2017. DOI: https://doi.org/10.14295/oh.v23i2.1070 
KHAN, W.; RAYIRATH, U.P.; SUBRAMANIAN, S.; JITHESH, M.N.; RAYORATH, P.; HODGES, D.M.; CRITCHLEY, A.T.; CRAIGIE, J.S.; NORRIE, J.; PRITHIVIRAJ, B. Seaweed extracts as biostimulants of plant growth and development. Journal of Plant Growth Regulation, v.28, n.4, p.386-399, 2009. DOI: https://doi. org/10.1007/s00344-009-9103-x

KUMAR, G.; SAHOO, D. Effect of seaweed liquid extract on growth and yield of Triticum aestivum var. Pusa Gold. Journal of Applied Phycology, v.23, p.251-255, 2011. DOI: http://dx.doi.org/10.1016/S2305-0500(13)60131-1

LABOURIAU, L.G. A germinação das sementes. Washington: Organização dos Estados Americanos, 1983. 174 .

LANA, A.M.Q.; LANA, R.M.Q.; GOZUEN, C.F.; BONOTTO, I.; TREVISAN, L.R. Aplicação de reguladores de crescimento na cultura do feijoeiro. Biosciencie Journal, v.25, n.1, p.13-20, 2009.

MAGUIRRE, J.D. Speed of germination-aid in selection and evaluation for seedling emergence and vigor. Crop Science, v.2, n.1, p.176-177, 1962. DOI: http://dx.doi. org/10.2135/cropsci1962.0011183x000200020033x

NEVES, M.F.; PINTO, M.J.A. Mapeamento e quantificação da cadeia de flores e plantas ornamentais do Brasil. São Paulo: OCESP, 2015. 122p.

OLIVEIRA, A.C.S.; MARTINS, G.N.; SILVA, R.F.; VIEIRA, H.D. Testes de vigor em sementes baseados no desempenho de plântulas. Inter Science Place, v.1, n.4, p.1-21, 2009.

PAIM, L.P.; AVRELLA, E.D.; FIOR, C.S. Germinação de sementes de Anadenanthera colubrina (Vellozo) Brenan em diferentes temperaturas. Revista da Jornada da PósGraduação e Pesquisa-Congrega Urcamp, v.13, p.573$582,2016$.

RAYORATH, P.; JITHESH, M.; FARID, A.; KHAN, W.; PALANISAMY, R.; HANKINS, S.D.; CRITCHLEY, A.T.; PRITHIVIRAJ, B. Rapid bioassays to evaluate the plant growth promoting activity of Ascophyllum nodosum (L.) Le Jol. using a model plant, Arabidopsis thaliana (L.) Heynh. Journal of Applied Phycology, v.20, n.4, p.423429, 2008a.

RAYORATH, P.; KHAN, W.; PALANISAMY, R.; MACKINNON, S.L.; STEFANOVA, R.; HANKINS, S.D.; CRITCHLEY, A.T.; PRITHIVIRAJ, B. Extracts of the brown seaweed Ascophyllum nodosum induce gibberellic acid (GA3)-independent amylase activity in barley. Journal of Plant Growth Regulation, v.27, n.4, p.370379, $2008 b$.
REIS, J.M.R.; RODRIGUES, J.F.; REIS, M.A. Doses e formas de aplicação de bioestimulante na produção de mudas de maracujazeiro. Cultura Agronômica, v.25, n.3, p.267-274, 2016.

SANGHA, J.S.; KELLOWAY, S.; CRITCHLEY, A.T.; PRITHIVIRAJ, B. Seaweeds (Macroalgae) and their extracts as contributors of plant productivity and quality: the current status of our understanding. Advances in Botanical Research - Sea Plants, v.71, p.189-213, 2014. DOI: 10.1016/B978-0-12-408062-1.00007

SANTOS, P.L.F.; CASTILHO, R.M.M. Germinação e desenvolvimento de plântulas ornamentais de girassol em substratos. Ornamental Horticulture, v.24, n.4, p.303310, 2018. DOI: http://dx.doi.org/10.14295/oh.v24i4.1152

SANTOS, P.L.F.; CASTILHO, R.M.M.; PINHEIRO, R.R. Seed position and influences on Caesalpinia pulcherrima germination and reserve proteins. Ornamental Horticulture, v.25, n.2, p.119-125, 2019. DOI: http:// dx.doi.org/10.14295/oh.v25i2.1727

SCHOENMAKER, P.K. O mercado de flores no Brasil. IBRAFLOR: Instituto Brasileiro de Floricultura. 5p. Available at: <https://www.ibraflor.com.br/numerossetor $>$. Acessed may $29^{\text {th }} 2019$.

SEBRAE. Flores e plantas ornamentais do Brasil. Série de estudos mercadológicos. Brasília: SEBRAE, 2015. $42 \mathrm{p}$.

SHARMA, H.S.S.; FLEMING, C.; SELBY, C.; RAO, J.R.; MARTIN, T. Plant biostimulats: a review on the processing of macroalgae and use of extracts for crop management to reduce abiotic and biotic stresses. Journal of Applied Phycology, v.26, n.1, p.465-490, 2014.

SILVA, R.C.B.; SANTANA, G.S.; LEITE, R.L.; NETO, M.R.B.; COELHO, F.J.S.; MONTEIRO, G.S. Emergência de sementes de girassol (Helianthusannuus) sob estresse salino irrigado por bombeamento fotovoltaico. Revista Semiárido De Visu, v.5, n.2, p.80-87, 2017.

TALAMINI, V.; STADNIK, M.J. Extratos vegetais e de algas no controle de doenças de plantas. In: STADNIK, M.J.; TALAMINI, V. Manejo ecológico de doenças de plantas. Florianópolis: Universidade Federal de Santa Catarina, 2004. p.45-62.

U.S. Department of Agriculture. 2017. Report results. Available at: $<9$ May 2017. <https://www.marketnews. usda.gov/mnp/fv-report-top-filters?locName $=\&$ commAbr $=$ SUNF\&commName $=$ SUNFLOWER\&class Name $=$ ORN AMENTALS\&rowDisplayMax $=25 \&$ startIndex $=1 \&$ navCl ass $=$ ORNAMENTALS\&navType $=$ byComm\&repType $=$ ter mPriceDaily\&type $=$ termPrice $>$. Accessed July, $16^{\text {th }} 2019$. 
UGARTE, R.A.; CRAIGIE, J.S.; CRITCHLEY, A.T. YARI, L.; DARYAEI, F.; SADEGHI, H. Evaluation of seed Fucoid flora of the rocky intertidal of the Canadian size and $\mathrm{NaCl}$ stress on germination and early seedling maritimes: implications for the future with rapid climate growth of sunflower (Helianthus annuus L.). International change. In: ISRAEL, A.; EINAV, R.; SECKBACH, J. Journal of Agronomy and Agricultural Research, v.7, (Eds.). Seaweeds and their role in globally changing n.3, p.60-65, 2015. environments. Heidelberg: Springer, 2010. p.69-90.

WALLY, O.S.D.; CRITCHLEY, A.T.; HILTZ, D.; CRAIGIE, J.S.; HAN, X.; ZAHARIA, L.I.; ABRAMS, S.R.; PRITHIVIRAJ, B. Regulation of phytohormone biosynthesis and accumulation in Arabidopsis flowing treatment with commercial extract from the marine macroalga Ascophyllum nodosum. Journal of Plant Growth Regulation, v.32, n.2, p.324-339, 2013. 